\title{
The expression of IL-20 and IL-24 and their shared receptors are increased in rheumatoid arthritis and spondyloarthropathy
}

\author{
Tue Wenzel Kragstrup ${ }^{\text {a,* }}$, Kristian Otkjaer ${ }^{\text {b }}$, Christian Holm ${ }^{\text {a }}$, Annette Jørgensen ${ }^{c}$, \\ Marianne Hokland ${ }^{\mathrm{a}}$, Lars Iversen ${ }^{\mathrm{b}}$, Bent Deleuran ${ }^{\mathrm{a}, \mathrm{c}}$ \\ a Institute of Medical Microbiology and Immunology, Aarhus University, Building 240, Wilhelm Meyers Allé, DK-8000 Aarhus C, Denmark \\ ${ }^{\mathrm{b}}$ Department of Dermato-Venereology, Aarhus University Hospital, P.P. Ørumsgade 11, DK-8000 Aarhus C, Denmark \\ ${ }^{c}$ Department of Rheumatology, Aarhus University Hospital, Nørrebrogade 44, DK-8000 Aarhus C, Denmark
}

Received 1 June 2007; received in revised form 2 October 2007; accepted 14 October 2007

\begin{abstract}
The purpose of this study was to analyze the expression of the two proinflammatory cytokines IL-20 and IL-24 and their shared receptors in rheumatoid arthritis and spondyloarthropathy. IL-20 was increased in plasma of rheumatoid arthritis patients compared with osteoarthritis patients and IL-24 was increased in synovial fluid and plasma of rheumatoid arthritis and spondyloarthropathy patients compared with osteoarthritis patients. IL-20 and IL-24 mRNA was only present at low levels in the synovium. In the synovial membrane, IL-20 protein was present in mononuclear cells and neutrophil granulocytes whereas IL-24 protein was observed in endothelial cells and mononuclear cells. IL-20 receptor type 1 and IL-22 receptor were expressed by granulocytes in the synovial fluid. In synovial fluid mononuclear cell cultures, stimulation with recombinant human IL-20 or recombinant human IL-24 induced monocyte chemoattractant protein 1 (CCL2/MCP-1) secretion, but not tumour necrosis factor $\alpha$ mRNA synthesis or IL-6 secretion. Both IL-20 and IL-24 showed correlations to CCL2/MCP-1 in plasma from rheumatoid arthritis and spondyloarthropathy patients. This study associates IL20 and IL-24 to the synovium of rheumatoid arthritis and spondyloarthropathy and results indicate that the two cytokines contribute to disease pathogenesis through recruitment of neutrophil granulocytes and induction of CCL2/MCP-1.
\end{abstract}

(c) 2007 Elsevier Ltd. All rights reserved.

Keywords: IL-20; IL-24; Arthritis

\section{Introduction}

Rheumatoid arthritis (RA) is an inflammatory disease that causes progressive joint damage and disability. In this inflammatory process, cytokines including IL-1, IL-6, IL-8, IL-10, monocyte chemoattractant protein 1 (CCL2/MCP$1)$, and tumour necrosis factor ( $\mathrm{TNF} \alpha)$ play a prominent role [1-3]. Spondyloarthropathy (SpA) comprises a group of related diseases characterized by spinal inflammation and peripheral joint oligoarthritis often including cutaneous manifestations. The role of cytokines is better characterized in RA than in SpA. However, TNFa blockers

\footnotetext{
${ }^{*}$ Corresponding author. Fax: +4586196128.

E-mail address: tue@immunology.au.dk (T.W. Kragstrup).
}

have been shown to be beneficial in the treatment of both psoriatic arthritis and ankylosing spondylitis suggesting a role for cytokines in the pathogenesis of these diseases [4-7].

IL-20 and IL-24 are two recently identified members of the IL-10 family of cytokines [8]. IL-20 expression has predominantly been described in monocytes [9], and keratinocytes [10], whereas IL-24 expression has primarily been found in macrophages [11,12], monocytes, $\mathrm{T}$ cells [9], and keratinocytes [10]. IL-20 and IL-24 signal through the receptor complexes IL-20 receptor type 1 (IL-20R1)/IL20 receptor type 2 (IL-20R2) and IL-22 receptor (IL22R)/IL-20R2 [13,14].

IL-20 has primarily been associated with psoriasis, as IL-20 expression in transgenic mice has been shown to 
cause skin abnormalities very similar to those observed in psoriasis [15]. Furthermore, the mRNA of IL-20 and of its three receptor subunits have been found in lesional psoriatic skin [16-18]. IL-24, also known as melanoma differentiation-associated gene 7, was discovered due to its ability to induce apoptosis in melanoma cells [19]. Furthermore, IL-24 has been shown to be expressed at increased levels in psoriasis [16].

The involvement of IL-20 and IL-24 in rheumatic diseases is not clarified. IL-20 and its three receptor subunits have been found in the synovial membrane of patients with RA [20,21]. IL-20 has also been shown to induce cytokine secretion in synovial fibroblasts, neutrophil chemotaxis, synovial fibroblast migration, and endothelial cell proliferation. Interestingly, the soluble IL-20R1 has been found to decrease the severity of collagen induced arthritis in rats suggesting that cytokines, which bind this receptor, are important in the pathogenesis of arthritis [20].

In this study, synovial fluid, plasma, and synovial membranes from RA and SpA patients were studied. Osteoarthritis (OA) patients served as non-inflammatory disease controls while healthy volunteers were included as normal controls. IL-20 and IL-24 levels were measured, the cellular sources and targets of IL-20 and IL-24 were studied and the effect of IL-20 and IL-24 on cytokine production was analyzed. This study provides new insight into the role of IL-20 in rheumatic diseases and presents the first association between IL-24 and these diseases.

\section{Materials and methods}

\subsection{Patients and samples}

Synovial fluid and plasma were collected from patients with RA $(n=24)$ and SpA $(n=22)$. Subgroups included under the category SpA were psoriatic arthritis $(n=11)$, reactive arthritis $(n=2)$, enteropathic arthritis associated with inflammatory bowel disease $(n=2)$, and undifferentiated spondyloarthritis $(n=7)$. The inclusion criteria were the requirement of therapeutic arthrocenthesis and the absence of anti-TNF $\alpha$ treatment. Patients with RA and $\mathrm{OA}$ were diagnosed in accordance with the criteria established by the American College of Rheumatology (ACR) $[22,23]$, patients with SpA were classified according to the European Spondyloarthropathy Study Group (ESSG) criteria [24], and psoriatic arthritis patients were diagnosed according to the CASPAR criteria [25]. OA patients $(n=15)$ were included to serve as non-inflammatory disease controls while normal healthy volunteers $(n=22)$ were also included to serve as controls. Synovial fluid and plasma were collected from patients with $\mathrm{OA}$ while only plasma was collected from normal healthy volunteers. Patient characteristics are listed in Table 1. Synovial fluid was collected during therapeutic arthrocenthesis, transferred to tubes containing EDTA, centrifuged and frozen. EDTA blood samples were collected in continuation of
Table 1

Characteristics of patients with RA, SpA, and OA and normal healthy volunteers (NHV) included for synovial fluid and/or plasma analysis

\begin{tabular}{|c|c|c|c|c|}
\hline Characteristic & $\begin{array}{l}\text { Patients } \\
\text { with RA } \\
(n=24)\end{array}$ & $\begin{array}{l}\text { Patients } \\
\text { with SpA } \\
(n=22)\end{array}$ & $\begin{array}{l}\text { Patients } \\
\text { with OA } \\
(n=15)\end{array}$ & $\begin{array}{l}\text { NHV } \\
(n=22)\end{array}$ \\
\hline Age, mean years & 55.3 & 44.6 & 71.1 & 41.1 \\
\hline Sex, no. of females & 21 & 18 & 8 & 11 \\
\hline $\begin{array}{l}\text { CRP, mean } \\
\text { concentration } \\
(\mathrm{nmol} / \mathrm{l})\end{array}$ & 278 & 128 & $<75$ & ND \\
\hline $\begin{array}{l}\text { Rheumatoid factor } \\
\text { positive, no. of } \\
\text { patients }\end{array}$ & 14 & 0 & 0 & ND \\
\hline \multicolumn{5}{|l|}{$\begin{array}{l}\text { Medications } \\
\text { received, no. of } \\
\text { patients }\end{array}$} \\
\hline None & 9 & 8 & 15 & 22 \\
\hline DMARD & 15 & 14 & 0 & 0 \\
\hline Methotrexate & 14 & 7 & - & - \\
\hline Salazopyrine & 6 & 6 & - & - \\
\hline Cloroquine & 3 & 0 & - & - \\
\hline Cyclosporine A & 1 & 1 & - & - \\
\hline Penicillamine & 0 & 1 & - & - \\
\hline
\end{tabular}

ND, not determined.

the therapeutic arthrocenthesis and plasma was harvested following centrifugation and frozen.

Synovial membranes were collected from a group of patients in connection with arthroplasty. Immunohistochemical staining was performed on samples from eight patients with RA (age, 62.9 mean years; sex, 7 females) and five patients with OA (age, 68.2 mean years; sex, 3 females).

All samples were obtained after informed consent according to the Danish Data Protection Agency, the Local Ethical Committee (Project Nos. 20050046 and 20060012) and the Declaration of Helsinki.

\section{2. $E L I S A$}

To quantify the concentration of IL-20 the Human IL20 ELISA Development Kit from PeproTech EC (UK) was used according to the manufacturer's recommendations. To quantify the concentration of IL-24 Maxisorp 96 well flat-bottom plates (NUNC) were coated with $5 \mu \mathrm{g} / \mathrm{ml}$ mouse IgG2b anti-IL-24 (R\&D, USA, MAB1965). Plates were then blocked with $1 \%$ BSA. Serial dilutions of recombinant human IL-24 (R\&D, 1965-IL025 ) and samples were added in duplicates followed by the addition of $1 \mu \mathrm{g} / \mathrm{ml}$ goat IgG anti-IL-24 (R\&D, AF1965). For detection, mouse IgG anti-goat HRP (Jackson, USA, 205-035-108) was added. The reaction was developed by incubating with ABTS substrate (SigmaAldrich, USA). The OD was read at $405 \mathrm{~nm}$ with a reference reading at $630 \mathrm{~nm}$. The minimum detectable concentration of human IL-24 for this ELISA system was $0.4 \mathrm{ng} / \mathrm{ml}$. Rheumatoid factor in patient samples did not seem to cross link capture and detection antibodies in the ELISA systems as low levels of cytokines were detected 
in both rheumatoid factor positive and rheumatoid factor negative patients. Following manufacturer's instructions, IL-6 was quantified by an ELISA system from BioLegend (USA) and CCL2/MCP-1 concentration was measured by an ELISA system from eBioscience (USA).

\subsection{Quantitative real-time PCR}

Synovial fluid mononuclear cells (SFMC) and peripheral blood mononuclear cells (PBMC) were obtained by Ficoll-Paque (Amersham Biosciences, Sweden) densitygradient centrifugation, transferred to SV RNA lysis buffer (Promega, USA) and frozen. Synovial membrane biopsies were snap-frozen in liquid nitrogen. Before RNA purification the synovial membranes were transferred to RNAlater-ICE (Ambion Inc., USA). RNA was purified with SV Total RNA Isolation System (Promega) as previously described [18]. For reverse transcription, Taqman Reverse Transcription Reagents (Applied Biosystems, USA) were used according to manufacturer's instructions. Reverse transcription thermal cycling conditions were a $25^{\circ} \mathrm{C}$ incubation step for $10 \mathrm{~min}$, followed by a $48^{\circ} \mathrm{C}$ reverse transcription step for $30 \mathrm{~min}$ and finally a $95^{\circ} \mathrm{C}$ reverse transcriptase inactivation step for $5 \mathrm{~min}$. Primers and probes were purchased from Applied Biosystems. IL-20, IL-24, and TNF- $\alpha$ mRNA expression was determined with a Taqman 20x Assays-On-Demand (FAM-labelled MGB-probes) gene expression assay mix (IL-20: Hs00218888_m1, IL-24: Hs00169533_m1, TNF- $\alpha$ : Hs00174128_m1). The housekeeping gene used for normalisation was 18s rRNA (Hs99999901_s1). The expression of each gene was analyzed in triplicates. PCR conditions were $2 \mathrm{~min}$ at $50^{\circ} \mathrm{C}, 10 \mathrm{~min}$ at $95^{\circ} \mathrm{C}$ followed by 50 cycles of $15 \mathrm{~s}$ at $95^{\circ} \mathrm{C}$ and $60 \mathrm{~s}$ at $60^{\circ} \mathrm{C}$. Relative gene expression levels were determined by using the relative standard curve method as previously described [18].

\subsection{Immunohistochemical analysis}

In the case of IL-20 staining, the synovial membranes were fixed in 4\% paraformaldehyde and embedded in paraffin. Samples were cut, de-paraffinized using xylene, rehydrated through ethanol and demasked by heating in Target Retrieval Solution (Dako, Denmark). Sections were blocked with 10\% goat serum (Dako, X0972) and Biotin Block (Dako) and were then incubated with $3 \mu \mathrm{g} / \mathrm{ml}$ mouse IgG1 anti-IL-20 (a kind gift from Novo Nordisk A/S, Denmark). Afterwards, biotinylated goat anti-mouse antibody (Dako, E0433) was added followed by the addition of StreptABComplex/AP (Dako). Finally, sections were stained with New Fuchsin substrate (Dako) with levamizole (Dako) and counterstained with Mayer's hematoxylin. For negative control, samples were incubated with $3 \mu \mathrm{g} / \mathrm{ml}$ mouse IgG1 isotype (Dako, X0931). Preincubation of the primary antibody with recombinant human IL-20 (a kind gift from Novo Nordisk A/S) resulted in negative staining (Fig. 3A).
In the case of IL-24 staining synovial membranes were embedded in Tissue-Tek and snap-frozen. Samples were cut and dehydrated in ice-cold acetone. Sections were blocked with $10 \%$ goat serum and Biotin Block and incubated with $5 \mu \mathrm{g} / \mathrm{ml}$ biotinylated goat IgG anti-IL-24 (R\&D, BAF1965) followed by incubation with StreptABComplex/AP. Staining was developed as above. For negative control, samples were incubated with $5 \mu \mathrm{g} / \mathrm{ml}$ goat IgG isotype (R\&D, BAF108). Preincubation of the primary antibody with recombinant human IL-24 resulted in negative staining (Fig. 3D). Double staining for IL-24 positive cells and endothelial cells was carried out using biotinylated goat IgG anti-IL-24 in combination with rabbit antivon Willebrand factor antibody (Dako, A082). For detection, streptavidin Texas Red (GE Healthcare Life Sciences, USA, RPN1233) and swine anti-rabbit FITC antibody (Dako, F205) were used.

\subsection{Flow cytometric analysis}

Synovial fluid cells were isolated from the synovial fluid by centrifugation and resuspension in 2\% FCS in PBS. Cells were blocked for unspecific binding with both $10 \%$ normal mouse serum and $10 \%$ rabbit serum (DAKO, X0902). Cells were stained with $10 \mu \mathrm{g} / \mathrm{ml}$ rabbit IgG antiIL-20R1 FITC and $10 \mu \mathrm{g} / \mathrm{ml}$ rabbit IgG anti-IL-22R FITC (binding to the extracellular part of the receptors, both a kind gift from Novo Nordisk A/S) in combination with either mouse IgG1 anti-CD3 PE (DAKO, R0810), mouse IgG1 anti-CD14 PE (Diatec, Norway, 3112) or mouse IgG1 anti-CD66 PE (BD, USA, 551478,). Ten micrograms per milliliter of rabbit IgG FITC isotype (Serotec, UK, PRABP01F) was used as negative control. Peripheral blood leucocytes from normal healthy volunteers were stained following the same procedure. The red blood cells were lysed by adding FACS Lysing Solution (BD). For positive control, keratinocytes were stained with both anti-receptor antibodies and the isotype antibody, as keratinocytes have previously been shown to express both IL20R1 and IL-22R [18] (Fig. 1).

\subsection{Cell culture}

SFMC were isolated from the synovial fluid by FicollPaque density-gradient centrifugation and cultured in RPMI medium supplemented with $10 \%$ FCS, penicillin, streptomycin, and glutamine at a concentration of $2 \times 10^{6}$ cells $/ \mathrm{ml}$. For stimulation experiments, recombinant human IL-20 was used at a concentration of $2000 \mathrm{pg} / \mathrm{ml}$, and recombinant human IL-24 was used at a concentration of $50 \mathrm{ng} / \mathrm{ml}$. For each setup a control cell culture with cells alone was used for comparison. Cells were cultured for $48 \mathrm{~h}$ at $37^{\circ} \mathrm{C}$ without changing of medium. After incubation supernatants were frozen for ELISA protein analysis, and cells were frozen in SV RNA lysis buffer for quantitative real time PCR (qRTPCR) mRNA analysis. 

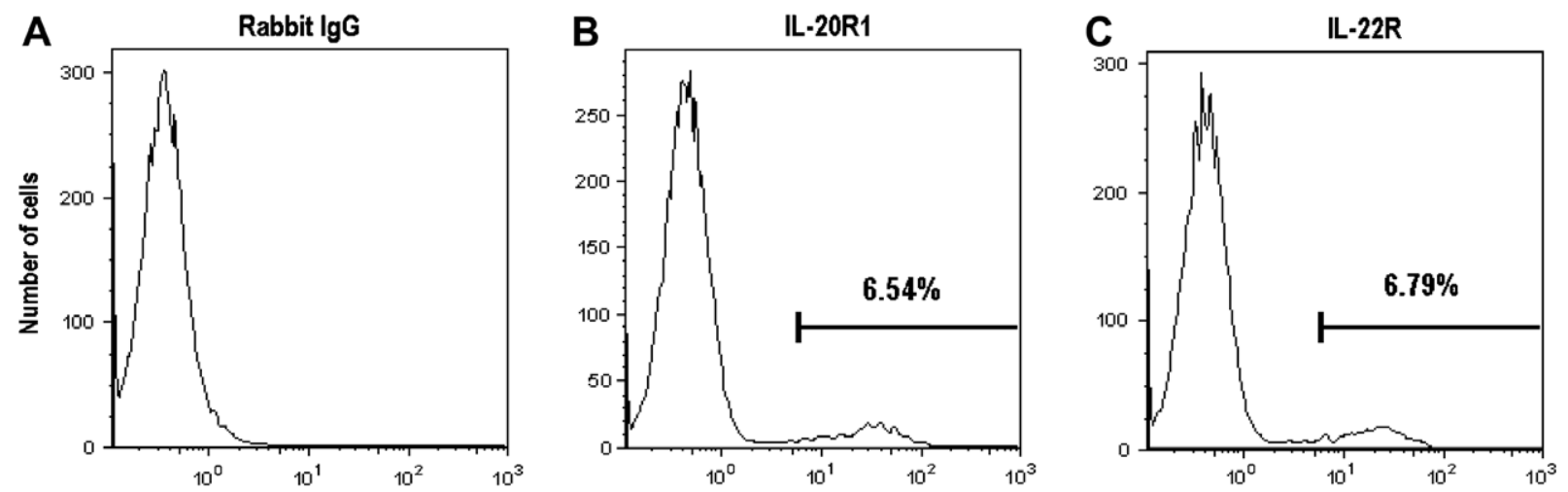

Fig. 1. IL-20R1 and IL-22R surface expression on keratinocytes. (A) No staining was observed with rabbit IgG isotype. (B) IL-20R1 and (C) IL-22R were expressed on a subpopulation of keratinocytes.

\subsection{Statistical analysis}

Statistical analyses were performed with the software program Prism 4 for Macintosh (GraphPad Software Inc., USA). The Mann-Whitney rank sum test was used for the analysis of differences between amounts of cytokines in patient groups, and the Spearman rank order correlation was used to calculate correlations between cytokines. In all tests the level of significance was a two-sided $P$ value of less than 0.05 . Results are expressed as the median with 25 th to 75 th percentiles in parenthesis.

\section{Results}

\subsection{IL-20 and IL-24 levels in synovial fluid and plasma}

The levels of IL-20 and IL-24 in synovial fluid and plasma from patients with RA, SpA, and OA and plasma from normal healthy volunteers were measured by ELISA. In synovial fluid there were no differences in the levels of IL-20 between the three groups. IL-20 in plasma from RA patients $(282 \mathrm{pg} / \mathrm{ml}$ (134-438 $\mathrm{pg} / \mathrm{ml})$ ) was significantly higher than in plasma from OA patients $(124 \mathrm{pg} / \mathrm{ml} \quad(110-147 \mathrm{pg} / \mathrm{ml})) \quad(P=0.006)$ (Fig. 2A).

IL-24 in synovial fluid from both RA $(2.25 \mathrm{ng} / \mathrm{ml}$ $(0-8.21 \mathrm{ng} / \mathrm{ml}))$ and $\mathrm{SpA}(3.81 \mathrm{ng} / \mathrm{ml}(0.30-11.0 \mathrm{ng} / \mathrm{ml}))$ patients was significantly higher than in synovial fluid from OA patients $(0 \mathrm{ng} / \mathrm{ml} \quad(0-0.72 \mathrm{ng} / \mathrm{ml})) \quad(P=0.01$ and $P=0.0005$, respectively). IL -24 in plasma from both RA $(2.21 \mathrm{ng} / \mathrm{ml} \quad(0.31-7.29 \mathrm{ng} / \mathrm{ml}))$ and $\mathrm{SpA} \quad(2.02 \mathrm{ng} / \mathrm{ml}$ $(0-6.83 \mathrm{ng} / \mathrm{ml}))$ patients was significantly higher than in plasma from OA patients $(0 \mathrm{ng} / \mathrm{ml} \quad(0-0 \mathrm{ng} / \mathrm{ml}))$ $(P=0.001$ and $P=0.005$, respectively). IL-24 in plasma from RA patients was significantly higher than in plasma from normal healthy volunteers $(0.08 \mathrm{ng} / \mathrm{ml}(0-3.63 \mathrm{ng} / \mathrm{ml}))$ $(P=0.03)$ (Fig. 2B).
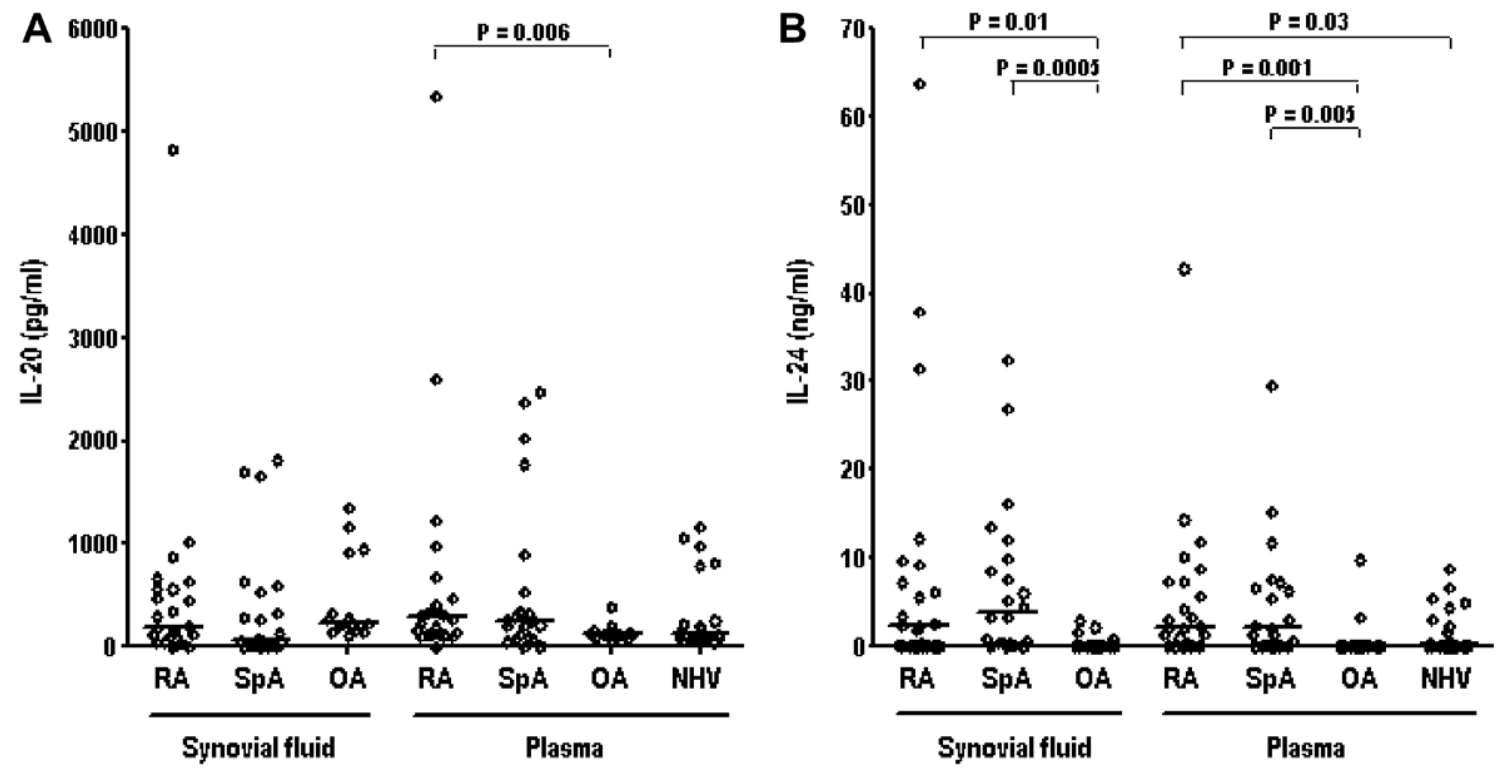

Fig. 2. Levels of IL-20 and IL-24 in synovial fluid and plasma from patients with RA, SpA, OA, and normal healthy volunteers (NHV). Lines represent the median level and the bars indicate the level of significance. Each dot represents one sample. 


\subsection{IL-20 and IL-24 $m R N A$ expression in synovial membrane cells and SFMC}

IL-20 and IL-24 mRNA in synovial membrane biopsies from RA and OA patients, SFMC from RA and SpA patients and $\mathrm{PBMC}$ from normal healthy volunteers were measured by qRT-PCR. Low levels of IL-20 and IL-24 mRNA were expressed in the synovial membrane biopsies of RA patients without differences between RA and OA patients (data not shown). Also, only low amounts of IL20 and IL-24 mRNA were found in SFMC from RA and SpA patients and in PBMC from healthy persons with no observable differences (data not shown).

\subsection{Localisation of IL-20 and IL-24 in the synovial membrane}

The localisation of IL-20 and IL-24 in synovial membranes from patients with RA and OA were analyzed by immunohistochemistry. IL-20 staining was evident in synovial biopsies of all RA patients, selectively in the sublining mononuclear cells and in infiltrating granulocytes (Fig. 3B and C). IL-20 staining was also detectable in the synovial biopsies from OA patients, but only a small number of positive cells were present.

IL-24 was detectable in all synovial biopsies from RA patients. The cells showing the highest expression of IL24 were the endothelial cells of the synovial blood vessels, while mononuclear cells of the sublining layer were more weakly stained (Fig. 3E and F). To confirm the staining of endothelial cells immunoflourescence double staining with anti-IL-24 and anti-von Willebrand factor was per- formed showing co-localisation (data not shown). IL-24 staining in the synovial biopsies of OA patients was weaker with discreet staining of endothelial cells and without staining of mononuclear cells.

\subsection{IL-20RI and IL-22R expression on synovial fluid cells}

The expression of IL-20R1 and IL-22R on the synovial fluid cells from RA and SpA patients and on peripheral blood leukocytes from normal healthy volunteers was measured by flow cytometry. The receptor subunits were found on a subset of CD66 positive cells (Fig. 4) while CD3 and CD14 positive cells did not express IL-20R1 and IL-22R. The frequency of CD66 positive synovial fluid cells that also expressed IL-20R1 and IL-22R was $3.16 \%$ (2.13$5.19 \%)$ and $2.81 \%(2.50-5.80 \%)$, respectively. The frequency of CD66 positive peripheral blood cells that also expressed IL-20R1 and IL-22R was $0.89 \%(0.56-1.27 \%)$ and $0.78 \%(0.62-0.95 \%)$, respectively. For both IL-20R1 and IL-22R, the expression on CD66 positive synovial fluid cells was significantly higher than that on CD66 positive peripheral blood leucocytes $(P=0.001)$ (data not shown).

\subsection{Effects of IL-20 and IL-24 on production of CCL2I $M C P-1, T N F \alpha$, and $I L-6$}

The effect of IL-20 and IL-24 on CCL2/MCP-1, TNF $\alpha$ and IL-6 production in SFMC cultures from RA patients and SpA patients was examined. The concentrations of IL-20 and IL-24 used in the in vitro experiments were similar to the highest concentrations that were found in patient synovial fluid samples. The levels of CCL2/MCP-1 and

IL-20
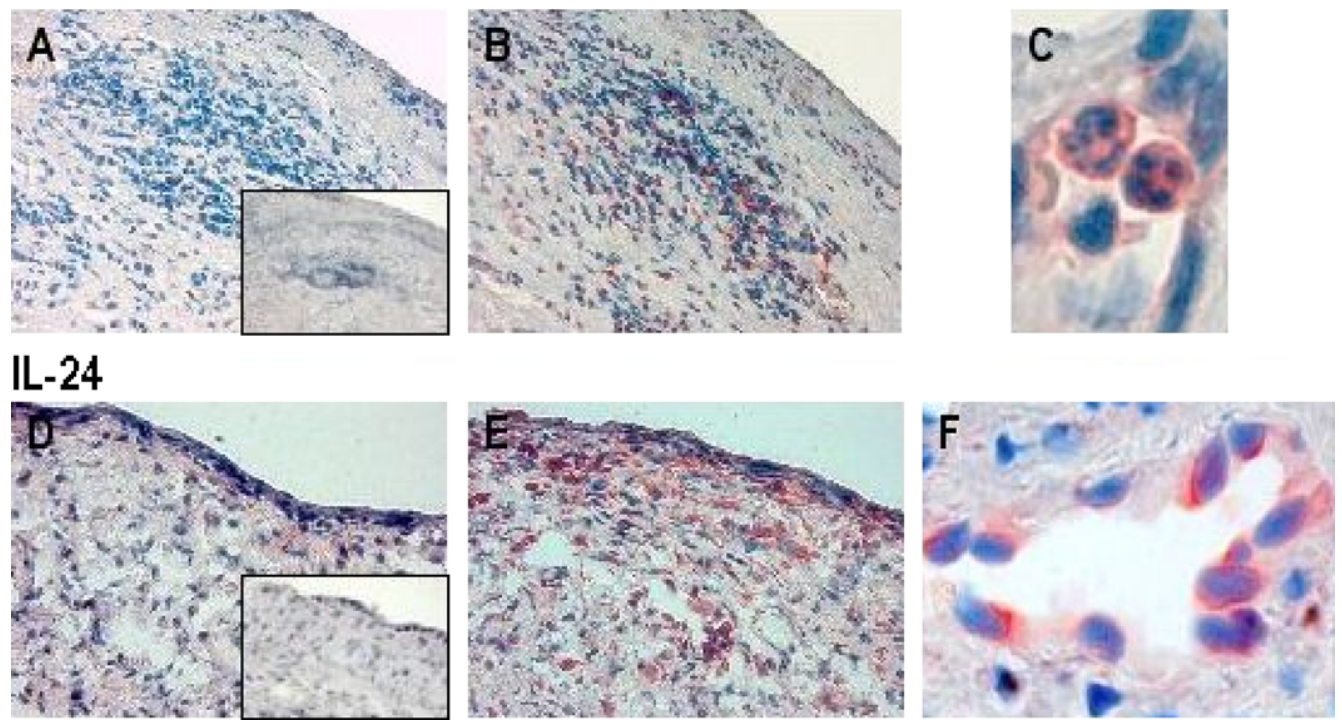

Fig. 3. Distribution of IL-20 and IL-24 in the RA synovial membrane. (A) No staining was observed with mouse IgG1 isotype or after preincubation of the anti-IL-20 antibody with recombinant human IL-20 (inset). (B) IL-20 staining was observed in mononuclear cells distributed in the sublining layer and (C) in infiltrating granulocytes. (D) No staining was observed with goat IgG isotype or after preincubation of the anti-IL-24 antibody with recombinant human IL-24 (inset). (E) IL-24 was observed in sublining mononuclear cells and (F) in endothelial cells of the synovial blood vessels. 

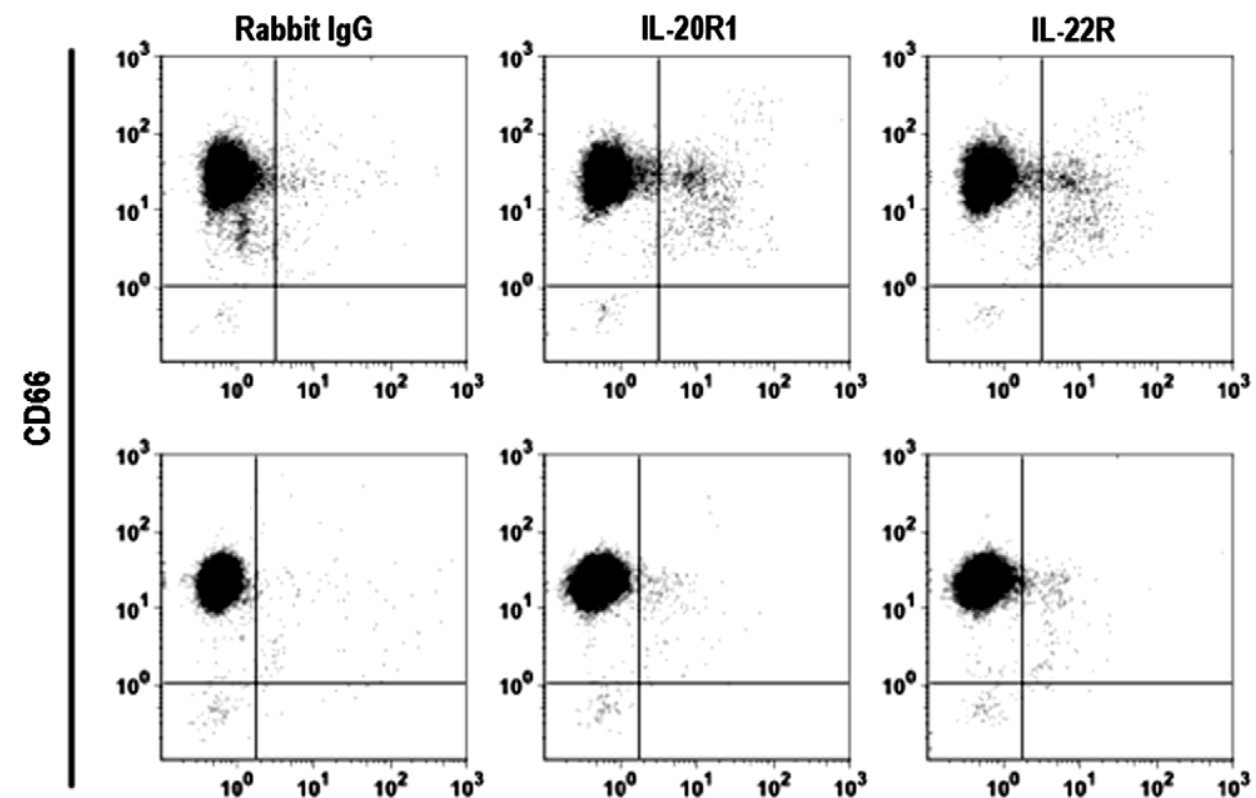

\section{Synovial \\ fluid cells}
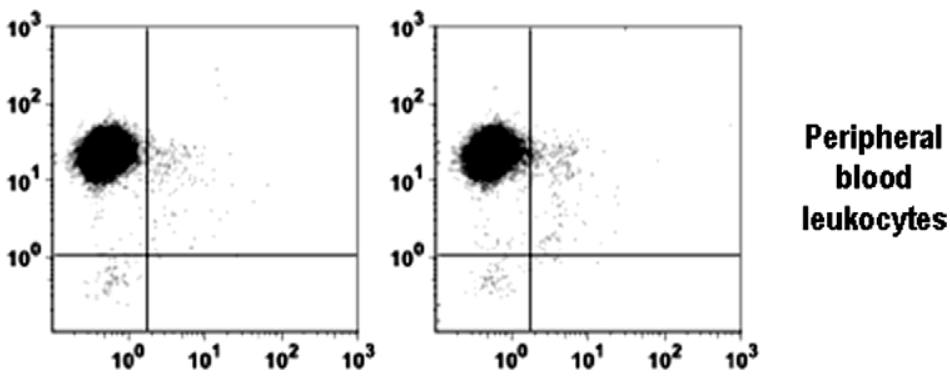

Fig. 4. IL-20R1 and IL-22R expression on synovial fluid cells of RA and SpA patients and on peripheral blood leukocytes of normal healthy volunteers. In both RA and SpA patients (synovial fluid cells) and normal healthy volunteers (peripheral blood leukocytes), IL-20R1 and IL-22R were found on a subpopulation of CD66 positive cells. No staining was observed with rabbit IgG isotype.

IL-6 in SFMC culture supernatants were measured by ELISA. TNF $\alpha$ mRNA in SFMC was measured by qRTPCR because the levels of TNF $\alpha$ in supernatants were in the region of the detection limits of the ELISA system. Addition of recombinant human IL-20 increased the production of CCL2/MCP-1 1.6-fold and the addition of recombinant human IL-24 increased the production of CCL2/MCP-1 1.8-fold. TNF $\alpha$ and IL-6 production were unchanged (data not shown).

The discovery of the stimulatory effect of IL-20 and IL24 on the production of CCL2/MCP-1 led to the examination of a possible correlation between IL-20 and IL-24 levels and levels of CCL2/MCP-1 in synovial fluid and plasma from RA and SpA patients. Significant positive correlations were observed between CCL2/MCP-1 and IL-20 in plasma from RA and SpA patients $(P=0.003)$ (Fig. 5A) and between CCL2/MCP-1 and IL-24 in both plasma and synovial fluid from RA and SpA patients $(P=0.001$ and $P=0.0001$, respectively) (Fig. 5B and C).

\section{Discussion}

This study is the first to investigate the expression profile of IL-20 in SpA and provides the first association between IL-24 and rheumatic diseases. The results indicate interesting and distinct roles for IL-20 and IL-24 in RA and SpA. IL-20 and IL-24 levels in RA and SpA patients were increased 1.5- to 2.5-fold in comparison with non-inflammatory disease controls and normal controls. RA and SpA patients had similar levels of IL-20 and IL-24. The level of IL-24 was around 10 times higher than that of IL-20 in the synovial fluid. Because the two cytokines share receptor complexes, this suggests that IL-24 plays a dominant role locally in the joint. The IL-24 level in this study was similar to the level of IL-24 found in a previous study while the level of IL-20 measured in this study was a factor 1000 lower than the IL-20 level measured in another recently published study $[20,26]$. Furthermore, the latter study also showed a difference between local and systemic
A

$$
r=0.41, P=0.003
$$

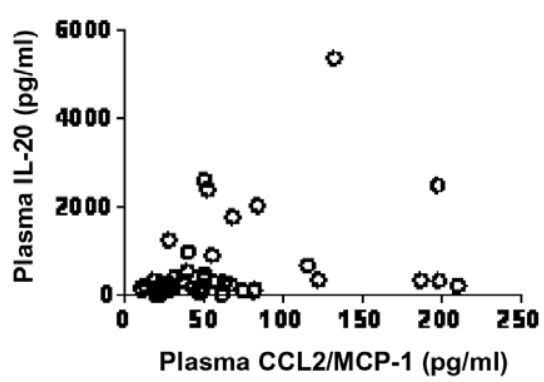

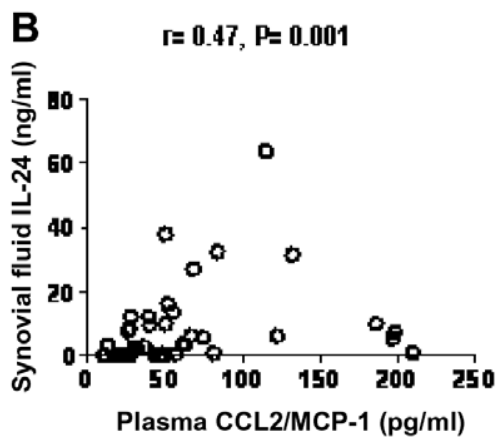

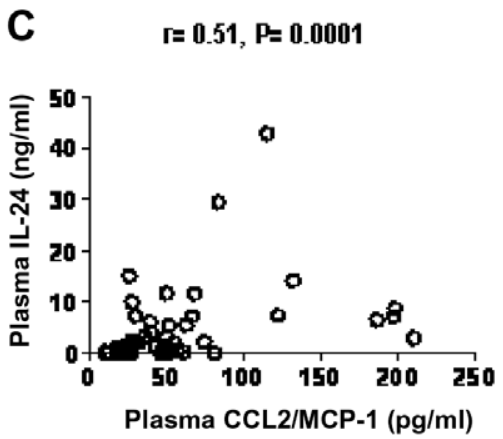

Fig. 5. Correlations of CCL2/MCP-1 with IL-20 and IL-24 in RA and SpA patients. Significant positive correlations were observed between levels of CCL2/MCP-1 in plasma and (A) IL-20 in plasma and between levels of CCL2/MCP-1 in plasma and IL-24 in both (B) synovial fluid and (C) plasma. 
levels of IL-20. The reason for the discrepancy is not known.

The low levels of IL-20 and IL-24 mRNA observed in the synovium of RA and SpA patients and the similar concentrations of the two cytokines found in synovial fluid and plasma suggest that the cellular sources of the two cytokines are located outside the synovial joint. A recent study has proposed that epidermal alterations in chemokine and cytokine expression initiate not only skin lesions but also arthritis in a psoriasis model [27]. This further supports the hypothesis that alterations in IL-20 and IL-24 production outside the synovial joint contribute to rheumatic disease. A complementary source of IL-20 and IL-24 could be peripherally activated mononuclear cells infiltrating the synovial joint, as it has previously been shown that peripherally activated cells infiltrate the synovial joint in rheumatic diseases [28]. In further support of this theory, IL20 and IL-24 protein were found in mononuclear cells in this study, and previous studies have observed IL-20 and IL-24 production by monocytes [9].

The IL-20 and IL-24 found in the synovial joint of RA and SpA patients indicate that these cytokines have targeted cells at this location, but the specific cellular target subpopulation of IL-20 and IL-24 may be very difficult to clarify. This is partly because the functional receptor for the two cytokines is composed of two receptor subunits, and partly because both cytokines can use either of the two receptor complexes IL-20R1/IL-20R2 and IL-22R/IL20R2. It is not understood how IL-20 and IL-24 compete for the same receptors on their target cells. The complexity is further increased because IL-19 can also signal through the receptor complex IL-20R1/IL-20R2 [13,14].

It has previously been shown that IL-20 can induce neutrophil chemotaxis [20]. In this study, IL-20R1 and IL-22R were expressed on granulocytes from the synovial fluid of RA and SpA patients indicating that IL-20 and IL-24 could be implicated in neutrophil chemotaxis in arthritis. Moreover, IL-20 was observed in infiltrating granulocytes in the synovial membrane of RA patients further supporting a functional role of granulocytes as target cells for IL20. In line with a recent study, the two receptor subunits were not detected on monocytes and lymphocytes [29].

IL-24 was observed in endothelial cells of the synovial blood vessels. This suggests an important role of these cells in the biological function of IL-24. Supporting an association of endothelial cells with IL-20 and IL-24 the receptor subunits for the two cytokines have previously been found on endothelial cells [30] and both IL-20 and IL-24 have been associated with angiogenesis. IL-20 has been shown to both induce and inhibit angiogenesis, while IL-24 has been found to be anti-angiogenic [31-33].

It seems that IL-20 and IL-24 have some similar roles in the cytokine network in rheumatic disease. IL-20 and IL-24 did not increase the TNF $\alpha$ mRNA expression or the production of IL-6 in SFMC cultures suggesting that IL-20 and IL-24 do not directly induce the production of these cytokines in arthritis. IL-20 and IL-24 in physiological concentrations induced the production of CCL2/MCP-1 in SFMC cultures implicating the two cytokines in the recruitment of mononuclear cells to the synovial joint by CCL2/MCP-1. This connection was further supported by the positive correlations between the two cytokines and CCL2/MCP-1 in patient samples. These correlations are also of interest because CCL2/MCP-1 has been shown to correlate to the number of swollen joints in RA [34]. The positive correlations to this pseudo-parameter of disease activity therefore also strengthen the association of IL-20 and IL-24 with RA and SpA.

This study associates IL-20 and IL-24 to the synovium of RA and SpA. The mononuclear cells in the synovial membrane could play a critical role in the biological function of IL-20 while IL-24 seems important for endothelial cell function. IL-20 and IL-24 could be implicated in the recruitment of granulocytes and mononuclear cells to the synovial joint.

\section{Acknowledgments}

We thank Eva Lykke Petersen from the Institute of Medical Microbiology and Immunology for excellent technical assistance, Jes Thorn Clausen from Novo Nordisk A/ $\mathrm{S}$ for donation of antibodies and cytokines, the Danish Rheumatism Association, the Danish Psoriasis Association. Tue Wenzel Kragstrup was supported by a grant from the Danish Medical Research Council (271-06-0014).

\section{References}

[1] Feldmann M, Brennan FM, Maini RN. Role of cytokines in rheumatoid arthritis. Annu Rev Immunol 1996;14:397-440.

[2] Bresnihan B, Tak PP. Synovial tissue analysis in rheumatoid arthritis. Baillieres Best Pract Res Clin Rheumatol 1999;13:645-59.

[3] Lee DM, Weinblatt ME. Rheumatoid arthritis. Lancet 2001;358:903-11.

[4] Reveille JD, Arnett FC. Spondyloarthritis: update on pathogenesis and management. Am J Med 2005;118:592-603.

[5] van Kuijk AW, Reinders-Blankert P, Smeets TJ, Dijkmans BA, Tak PP. Detailed analysis of the cell infiltrate and the expression of mediators of synovial inflammation and joint destruction in the synovium of patients with psoriatic arthritis: implications for treatment. Ann Rheum Dis 2006;65:1551-7.

[6] Kruithof E, Baeten D, De Rycke L, Vandooren B, Foell D, Roth J, et al. Synovial histopathology of psoriatic arthritis, both oligo- and polyarticular, resembles spondyloarthropathy more than it does rheumatoid arthritis. Arthritis Res Ther 2005;7:R569-80.

[7] Kavanaugh A, Tutuncu Z, Catalan-Sanchez T. Update on anti-tumor necrosis factor therapy in the spondyloarthropathies including psoriatic arthritis. Curr Opin Rheumatol 2006;18:347-53.

[8] Pestka S, Krause CD, Sarkar D, Walter MR, Shi Y, Fisher PB. Interleukin-10 and related cytokines and receptors. Annu Rev Immunol 2004;22:929-79.

[9] Wolk K, Kunz S, Asadullah K, Sabat R. Cutting edge: immune cells as sources and targets of the IL-10 family members?. J Immunol 2002;168:5397-402.

[10] Grone A. Keratinocytes and cytokines. Vet Immunol Immunopathol 2002;88:1-12.

[11] Garn H, Schmidt A, Grau V, Stumpf S, Kaufmann A, Becker M, et al. IL-24 is expressed by rat and human macrophages. Immunobiology 2002;205:321-34. 
[12] Poindexter NJ, Walch ET, Chada S, Grimm EA. Cytokine induction of interleukin-24 in human peripheral blood mononuclear cells. J Leukoc Biol 2005;78:745-52.

[13] Dumoutier L, Leemans C, Lejeune D, Kotenko SV, Renauld JC. Cutting edge: STAT activation by IL-19, IL-20 and mda-7 through IL-20 receptor complexes of two types. J Immunol 2001;167:3545-9.

[14] Parrish-Novak J, Xu W, Brender T, Yao L, Jones C, West J, et al. Interleukins 19, 20, and 24 signal through two distinct receptor complexes. Differences in receptor-ligand interactions mediate unique biological functions. J Biol Chem 2002;277:47517-23.

[15] Blumberg H, Conklin D, Xu WF, Grossmann A, Brender T, Carollo $S$, et al. Interleukin 20: discovery, receptor identification, and role in epidermal function. Cell 2001;104:9-19.

[16] Romer J, Hasselager E, Norby PL, Steiniche T, Thorn Clausen J, Kragballe K. Epidermal overexpression of interleukin-19 and -20 mRNA in psoriatic skin disappears after short-term treatment with cyclosporine a or calcipotriol. $\mathbf{J}$ Invest Dermatol 2003;121:1306-11.

[17] Wei CC, Chen WY, Wang YC, Chen PJ, Lee JY, Wong TW, et al. Detection of IL-20 and its receptors on psoriatic skin. Clin Immunol 2005;117:65-72.

[18] Otkjaer K, Kragballe K, Funding AT, Clausen JT, Noerby PL, Steiniche T, et al. The dynamics of gene expression of interleukin-19 and interleukin-20 and their receptors in psoriasis. Br J Dermatol 2005;153:911-8.

[19] Jiang H, Lin JJ, Su ZZ, Goldstein NI, Fisher PB. Subtraction hybridization identifies a novel melanoma differentiation associated gene, mda-7, modulated during human melanoma differentiation, growth and progression. Oncogene 1995;11:2477-86.

[20] Hsu YH, Li HH, Hsieh MY, Liu MF, Huang KY, Chin LS, et al. Function of interleukin-20 as a proinflammatory molecule in rheumatoid and experimental arthritis. Arthritis Rheum 2006;54:2722-33.

[21] Ikeuchi H, Kuroiwa T, Hiramatsu N, Kaneko Y, Hiromura K, Ueki $\mathrm{K}$, et al. Expression of interleukin-22 in rheumatoid arthritis: potential role as a proinflammatory cytokine. Arthritis Rheum 2005;52:1037-46.

[22] Arnett FC, Edworthy SM, Bloch DA, McShane DJ, Fries JF, Cooper NS, et al. The American Rheumatism Association 1987 revised criteria for the classification of rheumatoid arthritis. Arthritis Rheum 1988;31:315-24.

[23] Altman R, Asch E, Bloch D, Bole G, Borenstein D, Brandt K, et al. Development of criteria for the classification and reporting of osteoarthritis. Classification of osteoarthritis of the knee. Diagnostic and Therapeutic Criteria Committee of the American Rheumatism Association. Arthritis Rheum 1986;29:1039-49.

[24] Dougados M, van der Linden S, Juhlin R, Huitfeldt B, Amor B, Calin A, et al. The European Spondylarthropathy Study Group preliminary criteria for the classification of spondylarthropathy. Arthritis Rheum 1991;34:1218-27.

[25] Taylor W, Gladman D, Helliwell P, Marchesoni A, Mease P, Mielants H. Classification criteria for psoriatic arthritis: development of new criteria from a large international study. Arthritis Rheum 2006;54:2665-73.

[26] Sainz-Perez A, Gary-Gouy H, Portier A, Davi F, Merle-Beral H, Galanaud P, et al. High Mda-7 expression promotes malignant cell survival and p38 MAP kinase activation in chronic lymphocytic leukemia. Leukemia 2006;20:498-504.

[27] Zenz R, Eferl R, Kenner L, Florin L, Hummerich L, Mehic D, et al. Psoriasis-like skin disease and arthritis caused by inducible epidermal deletion of Jun proteins. Nature 2005;437:369-75.

[28] Kohem CL, Brezinschek RI, Wisbey H, Tortorella C, Lipsky PE, Oppenheimer-Marks N. Enrichment of differentiated CD45RBdim,CD27- memory T cells in the peripheral blood, synovial fluid, and synovial tissue of patients with rheumatoid arthritis. Arthritis Rheum 1996;39:844-54.

[29] Kunz S, Wolk K, Witte E, Witte K, Doecke WD, Volk HD, et al. Interleukin (IL)-19, IL-20 and IL-24 are produced by and act on keratinocytes and are distinct from classical ILs. Exp Dermatol 2006;15:991-1004.

[30] Chada S, Mhashilkar AM, Ramesh R, Mumm JB, Sutton RB, Bocangel D, et al. Bystander activity of Ad-mda7: human MDA-7 protein kills melanoma cells via an IL-20 receptor-dependent but STAT3-independent mechanism. Mol Ther 2004;10:1085-95.

[31] Heuze-Vourc'h N, Liu M, Dalwadi H, Baratelli FE, Zhu L, Goodglick L, et al. IL-20, an anti-angiogenic cytokine that inhibits COX-2 expression. Biochem Biophys Res Commun 2005;333:470-5.

[32] Hsieh MY, Chen WY, Jiang MJ, Cheng BC, Huang TY, Chang MS. Interleukin-20 promotes angiogenesis in a direct and indirect manner. Genes Immun 2006;7:234-42.

[33] Ramesh R, Mhashilkar AM, Tanaka F, Saito Y, Branch CD, Sieger $\mathrm{K}$, et al. Melanoma differentiation-associated gene 7/interleukin (IL)-24 is a novel ligand that regulates angiogenesis via the IL-22 receptor. Cancer Res 2003;63:5105-13.

[34] Ellingsen T, Buus A, Stengaard-Pedersen K. Plasma monocyte chemoattractant protein 1 is a marker for joint inflammation in rheumatoid arthritis. J Rheumatol 2001;28:41-6. 